\title{
Оцінка віддалених результатів лікування хворих із ускладненим синдром діабетичної стопи та визначення ш.ляхів надання їм медико-соціальної допомоги
}

\begin{abstract}
Мета роботи: проаналізувати структуру віддалених результатів хворих іза ускладненим СДС з визначенням показника фізичного і психологічного компонентів здоров’я, стану їх протезування та корекції взуття в ортопедичній майстерні.

Матеріали і методи. Під наглядом перебували 724 хворі з ускладненим СДС віком від 36 до 87 років. У 71 (9,8 \%) пацієнта захворювання було обтяжене сепсисом. Померли 36 хворих із ускладненим СДС без сепсису (летальність 5,5 \%) та 42 з сепсисом (летальність 59,1 \%). На амбулаторне лікування виписали 617 хворих з ускладненим СДС та 29 пацієнтів, які перенесли сепсис. Терміни проведення контрольного огляду були 6 місяців, 1, 2, 3 та 5 років.

Результати досліджень та їх обговорення. Показник фізичного та психологічного компонентів здоров’я через півроку не перевищував $(43,2 \pm 4,7)$ ум. од. у хворих, котрим виконані “малі” ампутації та $(31,3 \pm 3,6)$ ум. од. $(\mathrm{P}<0,05)$ у пацієнтів після "високих" ампутацій. Через 2 роки покращення в цьому напрямку не відбувалося. Лише одна пацієнтка протезована, менш ніж 25 \% хворих користується ортопедичним взуттям. Серед хворих, які перенесли сепсис та були виписані із стаціонару протягом першого року чи навіть раніше, померли 11 (42,3 \%), а впродовж 2 - 3 років 12 (46,2 \%) хворих. Через 5 років отримано такі дані: з 364 хворих, яких оперували з приводу гангрени нижньої кінцівки, вижили 23 (6,3%), а “високу” ампутацію контрлатеральної кінцівки виконано 48 (13,2 \%) пацієнтам. 3253 пацієнтів, в анамнезі яких були “малі” ампутації, протягом 5 років були оперовані на передньому відділі стопи цієї ж кінцівки в 14,2 \% випадків (36 хворих), на контрлатеральній кінцівці - (12,2 \%) 31 хворий. Всього померли 127 (50,2 \%) пацієнтів. Дані інших 17 хворих (6,7 \%) з'ясувати не вдалося.

Віддалені результати у хворих з ускладненим СДС свідчать про відсутність динамічного спостереження за цими хворими на амбулаторному етапі лікування. Оптимально, щоб питання протезування хворих після “високих" ампутацій та підбір ортопедичного взуття пацієнтам після “малих” було б включено до Національної програми допомоги хворим на цукровий діабет.
\end{abstract}

Ключові слова: ускладнений синдром діабетичної стопи; сепсис; аналіз віддалених результатів.

Постановка проблеми і аналіз останніх досліджень та публікацій. За даними Міжнародної федерації цукрового діабету (IDF), на сьогодні у світі налічується 382 млн хворих на цукровий діабет (ЦД), а темпи зростання захворювання свідчать про те, що до 2035 р. їх кількість досягне 595 млн [3].

Кожної хвилини у світі помирають 6 пацієнтів від ускладнень ЦД, а в продовж 55 секунд виконують “високу” ампутацію нижньої кінцівки. Кожного року на 1 млн населення виконують 280 - 300 тис. операцій із ампутації нижньої кінцівки. У Європі цей показник складає 250 операцій на 1 млн населення, у Японії - 210, у Росії - 500, в Україні - 640. Результати епідеміологічних досліджень свідчать, що кількість пацієнтів із синдром діабетичної стопи (СДС) кожного року збільшується на 2 - 6 \% [4].

Нечисельна статистика свідчить, що пацієнтів, яким виконана “висока” ампутація нижньої кінцівки, через рік госпіталізують в стаціонар 3 явищами гнійно-некротичних ускладнень цієї ж або контрлатеральної кінцівки, а в продовж перших 2 - 3 років їм виконують ампутацію другої кінцівки. За даними інноваційного судинного центру (Москва, Росія), пацієнти після “високих” ампутацій помирають впродовж року в 50 \% випадків, а депресивні розлади спостерігають майже у 75 \% хворих [1]. Згідно з Концесією Американської діабетичної асоціації (АДА-17), лікарю обов'язково потрібно оцінити емоційний та психічний стан пацієнта під час першого візиту, а потім - проводити таку оцінку регулярно, навіть коли пацієнт не вказує на наявність проблем [2].

Мета роботи: 3'ясувати структуру віддалених результатів у хворих на ускладнений СДС і сепсис з визначенням показника фізичного і психологічного компонетнтів здоров'я, стану їх протезування та корекції взуття в ортопедичній майстерні.

Матеріали і методи. Обстежено в динаміці 724 хворі на ускладнений СДС віком від 36 до 87 років, які проходили лікування протягом 2006 - 2016 pр. у гнійно-септичному центрі з ліжками діабетичної стопи КУ “Міська клінічна лікарня № 3” м. Запоріжжя. У 71 (9,8 \%) пацієнта захворювання було обтяжене сепсисом.

Досліджувані хворі були розподілені таким чином: 1-ша група - хворі на ускладнений СДС без сепсису - 653 (90,2 \%), померли - 36, леталь- 
ність - 5,5 \%; 2-га група - з сепсисом - 71 (9,8 \%), померли - 42, летальність - 59,1\%.

Середній вік пацієнтів першої групи склав $(68,9 \pm 2,3)$ року, у другій групі - $(65,4 \pm 3,7)$ року. Із супутньої патології в обох групах найчастіше спостерігали: ішемічну хворобу серця, гіпертонічну хворобу та ожиріння, у 647 (89,4 \%) хворих зазначена патологія була симультанною.

Усі хворі на ускладнений СДС були оперовані під загальним знеболенням або (останнім часом) за допомогою подовженої блокади сідничного нерва. Як правило, їм виконували операції на передньому відділі стопи та “високі” операції.

371 хворого з сепсисом, 13 пацієнтів не оперували $з$ різних причин. 58 хворим виконані аналогічні операції, як і в першій групі.

Таким чином, в цілому, на кістково-суглобовому апараті виконано 397 “високих" ампутацій та 256 “малих”. Після перших померли 33 хворі (летальність - 8,3 \%). Летальність після “малих" ампутацій склала 1,2 \% (померли 3 пацієнтів).

Загалом, на амбулаторне лікування виписали 617 хворих з ускладненим СДС та 29 пацієнтів, що видужали від сепсису.

Аналіз віддалених результатів проведено у 646 пацієнтів, 3 них - 617 на ускладнений СДС та 26 (89,6 \%) пацієнтів, що видужали від сепсису та були виписані зі стаціонару.

Терміни проведення контрольного огляду 6 місяців, 1, 2, 3 та 5 років. У більшості випадків анкетування проводили по телефону.

Результати досліджень та їх обговорення. Показник фізичного та психологічного компонентів здоров’я через півроку не перевищував (43,2 \pm $4,7)$ ум. од. у хворих, котрим проведені “малі” ампутації та $(31,3 \pm 3,6)$ ум. од. $(\mathrm{P}<0,05)$ у пацієнтів після “високих" ампутацій.

“Висока” ампутація негативно впливала на фізичний та психологічний стан хворого. Хворі скаржилися на депресивний стан, фантомний біль, а також біль у контрлатеральній кінцівці. На жаль, протезування не використовувалося, найбільш застосовним допоміжним засобом для пересування був візок, меншою мірою “ходунки”.

Хворим, що перенесли “малі” ампутації, підбирали ортопедичне взуття. Але спостереження за такими пацієнтами протягом 5 років показало, що менш ніж 25 \% хворих ним користуються.

Аналіз показників фізичного та психологічного компонентів здоров'я пацієнтів, оперованих понад 2 роки, показує, що ніякого покращення в цьому напрямку не відбувається. Навпаки, психоемоційний стан пацієнтів не витримує ніякої критики, тому в подальшому даний показник не визначали.
Хворим, які перенесли сепсис, виконані оперативні втручання у стаціонарі були розподілені наступним чином: ампутації на рівні стегна - 20 (1 підгрупа), ампутації на рівні гомілки - 3 (2 підгрупа), операції на передньому відділі стопи 5 (3 підгрупа), розтин флегмони стопи - 1 (4 підгрупа). Протягом першого року чи навіть раніше померли 11 (42,3 \%) хворих.

Із пацієнтів 1 підгрупи - померли протягом 2 - 3 року 8 хворих, які не були оперовані; 7 пацієнтам виконані “високі” ампутації контрлатеральної кінцівки, з яких 4 померло. Останні пацієнти протягом 3 років живі, їх стан задовільний, жоден із пацієнтів не протезований, користуються милицями та інвалідними візками.

Із 2 підгрупи протягом року помер один хворий, 2 пацієнти протягом 3 років живі, одна із них - протезована.

Із 3 підгрупи протягом першого року помер один хворий, 3 - виконані “високі” ампутації цієї ж нижньої кінцівки через $2-4$ роки після виписування із стаціонару, один - у задовільному стані, ортопедичним взуттям не користується.

Один хворий 4 підгрупи помер через 3 місяці амбулаторного спостереження.

Наведені факти свідчать, що реабілітаційне лікування у хворих, що перенесли у стаціонарі сепсис, не проведено. Слід зазначити, що жоден пацієнт на активний виклик для обстеження не 3'явився, мотивуючи це поганим самопочуттям та депресивним станом. Тому проспективний аналіз був здійснений у телефонному режимі. Останній свідчив, що з 29 хворих, що перенесли сепсис у стаціонарі та були виписані на амбулаторне лікування, протягом 5 років померло 26 (89,7 \%) осіб, про долю трьох - не відомо.

Проаналізовано віддалені результати 617 хворих на ускладнений СДС, які були оперовані в центрі протягом 2006 - 2016 рр. та були виписані на амбулаторне лікування. Як було зазначено вище, всі 617 пацієнтів були оперовані і їм виконано 364 “високих” ампутацій та 253 “малих” на передньому відділі стопи.

Через 6 місяців для огляду та проведення планової судинної хірургії з'явилося лише 42 (6,8 \%) пацієнти. 3 них -3 хворі після “високих" ампутацій. Всі користуються милицями, госпіталізовані до стаціонару. 3'явилися на огляд 39 пацієнтів, що перенесли “малі” ампутації, 3 яких 26 (66,7 \%) відмовилися від госпіталізації з тих чи інших причин. Користуються ортопедичним взуттям 6 (15,4 \%) пацієнтів.

Через рік проведено анкетування 52 пацієнтів. У телефонному режимі з'ясовано, що 9 хворих померли після “високих” ампутацій та 3 - після “ма- 
лих”. Таким чином, на огляд з'явилося 40 пацієнтів, 3 них - 5 після “високих” ампутацій, госпіталізовані - 4 (троє з яких проводили лікування через 6 місяців), один - першого року, один - відмовився від госпіталізації. Ще у 2 хворих проведена “висока” ампутація контрлатеральної кінцівки, а 4 пацієнтам, що перенесли “малу” ампутацію, виконали “високу” ампутацію раніше оперованої кінцівки. Ніхто з хворих не протезований, окрім однієї пацієнтки, яка перенесла ампутацію на рівні верхньої третини гомілки.

Через 2 роки отримано такі дані: померли 17 хворих (8 - після “високих” ампутацій, 9 - після “малих”), з перших - 5 пацієнтам виконано “високу” ампутацію на контрлатеральні кінцівці (померло - 4). Виконані 2 “високі” ампутації кінцівки у хворих, що раніше були оперовані та перенесли “малі” ампутації на цій же кінцівці. 361 пацієнта, які з’явилися для огляду, госпіталізовано 29 (47,5 \%). Незадовільне матеріальне становище було основною причиною відмови для госпіталізації та проведення курсу судинної терапії. Слід зазначити, що жодного пацієнта після “високої” ампутації не протезували, вони користуються милицями та інвалідними візками. Невтішна ситуація з пацієнтами, які перенесли “малі” ампутації - користуються ортопедичним взуттям близько 25 \% хворих.

Ще гірші результати отримані через 3 роки. Померли 36 хворих (12 - після “високих" операцій, 24 - після “малих”). 3 перших - 7 пацієнтам виконано “високу” ампутацію контрлатеральної кінцівки (померло - 5). Більш високі ампутації кінцівки виконано хворим, у яких раніше були “малі” ампутації (померло - 7). На “активні” виклики хворі, що були оперовані 3 роки тому, 3’являлися лише (17 пацієнтів) 25 \%.

Через 5 років отримано такі дані: з 364 хворих, яких оперували 3 приводу гангрени нижньої кінцівки, вижили 23 (6,3%). Протягом п’яти років “високу” ампутацію контрлатеральної кінцівки виконано 48 (13,2 \%) пацієнтам. Хворі після операційних втручань не задоволені якістю життя, у всіх спостерігався виразний депресивний розлад, тільки одна пацієнтка протезована.

3253 пацієнтів, в анамнезі яких були “малі” ампутації, протягом п’яти років були оперовані на передньому відділі стопи цієї ж кінцівки 36 хворих (14,2 \%), на контрлатеральній кінцівці - 31 (12,3 \%). “Високу” ампутацію виконали 42 (16,6 \%) пацієнтам. Всього померли - 127 (50,2%) хворих. Про долю 17 (6,7 \%) пацієнтів не відомо.

Аналізуючи віддалені результати лікування, керувалися такими чинниками. “Добрими” вва- жали повне одужання, відсутність рецидиву на оперованій та контрлатеральній кінцівки. "Незадовільним” вважали результат, пов’язаний із рецидивом або ускладненням на ділянці післяопераційної рани, відсутність повного загоєння, остеомієліт, рецидив виразкоутворення, гнійно-запальні процеси контрлатеральної кінцівки, прогресування основного захворювання (ішемія, нейропатія, ретинопатія тощо) або супутнього (ішемічна хвороба серця, гіпертонічна хвороба, ниркова недостатність та ін.).

Слід зазначити, що при аналізі віддалених результатів лікування хворих на ускладнений СДС зберігали розподіл хворих згідно з етіологічним чинником на нейропатичну, ішемічну та змішану форму. Незалежно від етіологічного чинника, загальними проявами у хворих були дисбаланс м’язів, що призводив до утворення деформацій стопи, кігтеподібних та молоточкоподібних пальців; трофічні розлади шкіри (сухість, тріщини, гіперкератоз). Серед ускладнень спостерігали лігатурний абсцес, нориці, екзофіти.

Через півроку - рік динамічного спостереження позитивні результати відмічено у 36 (38,3 \%) пацієнтів, незадовільні - у 43 (45,7 \%), померли - 12 (12,8 \%), втрачено контакт у зв’язку зі зміною місця проживання - 3 (3,2 \%). Через 2 - 3 роки отримані такі дані: померли 53 хворі (41,1 \%), “добрі” результати - у 20 (15,5 \%) пацієнтів (всі - після “малих” ампутацій), незадовільні - у 51 (39,5 \%). У всіх останніх пацієнтів спостерігався виразний депресивний синдром. Втрачено контакт $з 5$ (3,9 \%) пацієнтами.

Невтішні результати спостерігали через 5 років. Загалом померли 468 (72,4 \%) пацієнтів, 3 них - 341 (93,7 \%) після “високих” ампутацій та 127 (50,0 \%) після “малих”. Про долю 31 (5,0%) пацієнта не відомо.

Вважаємо, що ризик рецидівів ускладненого СДС на оперованій або контрлатеральній кінцівці зростає при наявності таких чинників, як тривалість ЦД понад 10 років; його декомпенсація; діабетична периферійна полінейропатія; облітеруючий атеросклероз артерій нижніх кінцівок; зміни стопи (гіперкератоз, зниження рухливості суглобів, зони з надмірним плантарним тиском); нехтування носінням ортопедичного взуття.

Усім хворим з деформацією стопи та пальців 3 метою профілактики виразкоутворення призначали індивідуальні ортопедичні устілки. Але ретроспективний аналіз свідчив, що більшість хворих користувалася “первинними” устілками впродовж всього періоду часу і для їх корекції в ортопедичні майстерні не зверталися. 
На наш погляд, після операцій на передньому відділі стопи дуже важлива профілактика виникнення повторних ускладнень, основними якої $€$ адекватна корекція ЦД; самоконтроль та регулярні огляди фахівцями (ендокринологом, хірургом, терапевтом) не рідше один раз на рік; застосування ортопедичних корегувальних засобів (устілки, супінатори, протези, ортопедичне взуття).

Індивідуальний підхід для кожного конкретного пацієнта є основним напрямом розвитку профілактичної роботи щодо частоти розвитку ускладненого СДС.

Покращення результатів лікування хворих на ускладнений СДС можливо при вдосконаленні роботи лікувально-профілактичних закладів:

- створення регламентованої системи надання міждисциплінарної допомоги хворим на СДС з участю ендокринологів, лікарів-хірургів гнійносептичних відділень, судинних хірургів, ортопедів, дільничих та сімейних медичних сестер, соціальних працівників;

- створення спеціалізованих відділень 3 надання допомоги хворим на ускладнений СДС на базі багатопрофільних лікувально-профілактичних закладів;

- моніторинг захворювання, ускладненого СДС, кількості ампутацій та летальності в країні;

- налагодження післядипломної підготовки лікарів, медичних сестер, соціальних працівників для надання допомоги даній категорії хворих;

- удосконалення роботи кабінетів діабетичної стопи або подологічних кабінетів для надання амбулаторної допомоги хворим на СДС. Навчання хворих та членів їх сімей догляду за кінцівками, психологічної та соціальної адаптації інвалідів;

- оптимально, що б питання протезування хворих після “високих” ампутацій та підбір ор-

\section{СПИСОК ЛІТЕРАТУРИ}

1. Воробихина Н. В. Влияние метода оперативного лечения больных с гнойно-некротическими формами синдрома диабетической стопы на частоту рецидивирования, риск повторных операций и выживаемость / Н. В. Воробихина, Т. А. Зеленина, Т. М. Петрова // Инфекции в хирургии. 2009. - № 4. - С. 41-46.

2. Маньковский Б. Н. Диабетология: Что нового в клинических рекомендациях в 2017 году? / Б. Н. Маньковский // Здоров’я України. - Березень 2017. - С. 9.

\section{REFERENCES}

1. Vorobikhina, N.V., Zelenina, T.A., \& Petrova, T.M. (2009). Vliyanie metoda operativnogo lecheniya bolnykh $\mathrm{s}$ gnoyno-nekroticheskimi formami sindroma diabeticheskoy stopy na chastotu retsidivirovaniya, risk povtornykh operatsii i vyzhivayemost [Influence of the method of operative treatment of patients with purulent-necrotic forms of the diabetic foot syndrome on the frequency of recurrence, the risk of repeated топедичного взуття пацієнтам після “малих” було включено до Національної програми допомоги хворим на цукровий діабет.

Висновки. 1. Віддалені результати у хворих, що перенесли у стаціонарі сепсис, свідчать, що реабілітаційне лікування у цих пацієнтів не проведене. Протягом першого року чи навіть раніше померли 42,3 \% хворих, а через 5 років жоден пацієнт не вижив.

2. Виживаність пацієнтів, яких оперували 3 приводу гангрени нижньої кінцівки через 5 років, склала лише 6,3 \%, протягом цього періоду в 48 (13,2 \%) хворих виконано “високу” ампутацію контрлатеральної кінцівки.

3. Протягом 5 років пацієнти, в анамнезі яких “малі" ампутації, були оперовані на передньому відділі стопи цієї ж кінцівки в 14,2 \% випадків, на контрлатеральній кінцівки - в 12,3 \%. "Висока" ампутація виконана в 16,6 \% спостережень.

4. Показник фізичного та психологічного компонентів здоров'я оперованих пацієнтів втрачає значущість вже через рік після виписки хворих на амбулаторне лікування.

Питання протезування хворих після “високих" ампутацій та підбір ортопедичного взуття після “малих" повинно бути включено до Національної програми допомоги хворим на цукровий діабет.

Преспективи подальших досліджень Перспективним $є$ подальше дослідження віддалених результатів лікування хворих на ускладнений синдром діабетичної стопи, що дасть можливість, на основі показників фізичного та психічного здоров'я, розробляти нові алгоритми надання медико-соціальної допомоги.

3. Ткаченко В. І. Наукове обгрунтування та шляхи оптимізації ведення пацієнтів з цукровим діабетом 2 типу на стан первинної медичної допомоги : автореф. дис. на здобуття наук. ступеня докт. мед. наук: спец. 14.01.38 “Загальна практикасімейна медицина” / В. І. Ткаченко; ДЗ “ЗМАПО МОЗ України”. - Запоріжжя, 2016. - 40 с.

4. Шаповал С. Д. Сепсис із погляду етіологічного чинника / С. Д. Шаповал, І. Л. Савон, Д. О. Смирнова // Науковий вісник Ужгородського університета. - 2014. - Вип. 2 (50). C. $142-150$.

operations and survival]. Infektsii $v$ khirurgii - Infections in Surgery, (4), 41-46 [in Russian].

2. Mankovskiy, B.N. (2017). Diabetologiya: Chto novogo v klinicheskikh rekomendatsiyakh v 2017 godu? [Diabetology: What's new in clinical guidelines in 2017?]. Zdorovia Ukrainy Health of Ukraine, 9 [in Ukrainian].

3. Tkachenko, V.I. (2016). Naukove obhruntuvannia ta shliakhy 
optymizatsii vedennia patsiientiv z tsukrovym diabetom 2 typu na stan pervynnoi medychnoi dopomohy [Scientific substantiation and ways to optimize the management of patients with type 2 diabetes mellitus in the state of primary medical care]. Doctor's Extended abstract. Ministry of Health of Ukraine. Zaporizhzhia [in Ukrainian].
4. Shapoval, S.D., Savon I.L., \& Smyrnova, D.O. (2014). Sepsys iz pohliadu etiolohichnoho chynnyka [Sepsis from the point of view of the etiological factor]. Naukovyi visnyk Uzhhorodskoho universyteta - Scientific Journal of Uzhhorod University, 2 (50), 142-150 [in Ukrainian].

\author{
O. V. TRIBUSHNYI
}

Zaporizhzhia Medical Academy of Postgraduate Education

\title{
EVALUATION OF LONG-TERM RESULTS OF TREATMENT OF PATIENTS WITH COMPLICATED DIABETIC FOOT SYNDROME AND DETERMINATION OF WAYS OF RENDERING MEDICAL-SOCIAL ASSISTANCE
}

\begin{abstract}
The aim of the work. The structure of the long-term results of treatment of patients with complicated DFS with the definition of the indicator of the physical and psychological components of health, the state of their prosthetics and the correction of shoes in orthopedic workshops is analyzed.

Materials and Methods. There were 724 patients with complicated DFS aged 36 to 87 years under observation. In 71 (9.8 \%) patients, the disease was complicated by sepsis. 36 patients with complicated DFS without sepsis died (lethality $5.5 \%$ ) and 42 patients with sepsis (lethality $59.1 \%$ ). For outpatient treatment, 617 patients with complicated DFS and 29 patients who had sepsis were discharged. The terms of the control examination were: 6 months, 1, 2, 3 and 5 years.

Results and Discussion. The index of physical and psychological components of health in half a year did not exceed $43.2 \pm 4.7$ conv. units in patients who underwent "small" amputations and $31.3 \pm 3.6$ conv. units $(\mathrm{P}<0.05)$ in patients after "high" amputations. After 2 years, there was no improvement on the part of these spheres. Only one patient is prosthodontic, less than $25 \%$ of patients use orthopedic footwear. Patients who recovered from sepsis and were discharged from the hospital: 11 (42.3\%) died during the first year or even early, and 12 (46.2 \%) for 2 to 3 years. After 5 years, the following data were obtained: Among 364 patients who operated on gangrene of the lower extremity, 23 (6.3 \%) survived, and a "high" amputation of the contralateral limb was performed in 48 (13.2 \%) of patients, out of 253 patients, in the anamnesis of whom there were "small" amputations, for 5 years they operated on the forefoot of this limb in $14.2 \%$ of cases (36 patients), on the contralateral limb - 31 (12.2 \%), 127 (50.2 \%), the fate of the remaining 17 (6.7\%) is not established.

Long-term results in patients with complicated DFS testify to the absence of dynamic observation of these patients at the outpatient stage of treatment. It is optimal that the questions of prosthetic patients after "high" amputations and the selection of orthopedic shoes for patients after "small" would be included in the National Diabetes Care Program.
\end{abstract}

Key words: complicated diabetic foot syndrome; sepsis; analysis of long-term results.

\section{О. В. ТРИБУШНОЙ}

гУ“Запорожская медицинская академия последипломного образования МЗ Украины”

\section{ОЦЕНКА ОТДАЛЕННЫХ РЕЗУЛЬТАТОВ ЛЕЧЕНИЯ БОЛЬНЫХ С ОС.ОЖНЕННЫМ СИНДРОМОМ ДИАБЕТИЧЕСКОЙ СТОПЫ И ОПРЕДЕЛЕНИЕ ПУТЕЙ ОКАЗАНИЯ ИМ МЕДИКО-СОЦИАЛЬНОЙ ПОМОщИ}

\footnotetext{
Цель работы: проанализировать структуру отдаленных результатов лечения больных с осложненным СДС с определением показателя физического и психологического компонентов здоровья, состояние их протезирования и коррекции обуви в ортопедических мастерских.

Материалы и методы. Под наблюдением находилось 724 больных с осложненным СДС в возрасте от 36 до 87 лет. У 71 $(9,8 \%)$ пациентов заболевание было осложнено сепсисом. Умерло 36 больных с осложненным СДС без сепсиса (летальность 5,5 \%) и 42 - с сепсисом (летальность 59,1 \%). На амбулаторное лечение выписалось 617 больных с осложненным СДС и 29 пациентов, которые перенесли сепсис. Сроки проведения контрольного осмотра были 6 месяцев, 1, 2, 3 и 5 лет.

Результаты исследований и их обсуждение. Показатель физического и психологического компонентов здоровья через полгода не превышал $(43,2 \pm 4,7)$ усл. ед. у больных, которым были выполнены “малые” ампутации и $(31,3 \pm 3,6)$ усл. ед. $(\mathrm{P}<0,05)$ у пациентов после “высоких” ампутаций. Через 2 года никакого улучшения со стороны этих сфер не происходило. Только одна пациентка протезирована, менее чем 25 \% больных пользуются ортопедической обувью. Среди больных, которые
} 


\section{З ДОСВІДУ РОБОТИ}

выздоровели от сепсиса и были выписаны из стационара на протяжении первого года или даже раннее, умерло 11 (42,3 \%), а на протяжении 2 - 3-х лет - 12 (46,2 \%). Через 5 лет получены следующие данные: из 364 больных, которые оперировались по поводу гангрены нижней конечности остались в живых 23 (6,3 \%), а “высокая” ампутация контрлатеральной конечности выполнена у 48 (13,2 \%) пациентов. Из 253 пациентов, в анамнезе которых были “малые” ампутации, на протяжении 5 лет были оперированы на переднем отделе стопы этой же конечности в 14,2 \% случаев (36 больных), на контрлатеральной конечности 31 (12,2 \%) больной. Всего умерло 127 (50,2 \%) пациентов. Данные остальных 17 (6,7 \%) - не установлены.

Отдаленные результаты у больных с осложненным СДС свидетельствуют об отсутствии динамического наблюдения за этими больными на амбулаторном этапе лечения. Оптимально, чтобы вопросы протезирования больных после “высоких" ампутаций и подбор ортопедической обуви пациентов после “малых” было бы включено в Национальную программу помощи больным сахарным диабетом.

Ключевые слова: осложненный синдром диабетической стопы; сепсис; анализ отдаленных результатов. 